\title{
TGF-ß1/PTEN/PI3K signaling plays a critical role in the anti-proliferation effect of tetrandrine in human colon cancer cells
}

\author{
QIAN-ZHAO CHEN ${ }^{1,2^{*}}$, YANG LI $^{1,2^{*}}$, YING SHAO $^{1,2}$, YU-HUA ZENG $^{1,2}$, \\ WEN-YAN REN $^{1,2}$, RONG-XING LIU ${ }^{1,2}$, LIN-YUN ZHOU ${ }^{1,2}$, XUE-LIAN HU ${ }^{1,2,3}$, \\ MING HUANG ${ }^{2}$, FANG HE ${ }^{2}$, WEN-JUAN SUN ${ }^{1,2}, \mathrm{KE} \mathrm{WU}^{1,2}$ and BAI-CHENG HE ${ }^{1,2}$ \\ ${ }^{1}$ Department of Pharmacology, School of Pharmacy, Chongqing Medical University; \\ ${ }^{2}$ Chongqing Key Laboratory for Biochemistry and Molecular Pharmacology, Chongqing Medical University, \\ Chongqing 400016; ${ }^{3}$ Department of Pharmacy, Second Affiliated Hospital of the \\ Third Military Medical University, Chongqing 400037, P.R. China
}

Received November 2, 2016; Accepted January 31, 2017

DOI: $10.3892 /$ ijo. 2017.3875

\begin{abstract}
The diagnosis and treatment for colon cancer have been greatly developed, but the prognosis remains unsatisfactory. There is still a great clinical need to explore new efficacious drugs for colon cancer treatment. Tetrandrine (Tet) is a bis-benzylisoquinoline alkaloid. It has been shown that Tet may be a potential candidate for cancer treatment, but the explicit mechanism underlying this activity remains unclear. In this study, we investigated the anticancer activity of Tet in human colon cancer cells and dissected the possible mechanism. With cell viability assay and flow cytometry analysis, we confirmed that Tet can effectively inhibit the proliferation and induce apoptosis in HCT116 cells. Mechanically, we found that Tet greatly increases the mRNA and protein level of TGF- $\beta 1$ in HCT116 cells. Exogenous TGF- $\beta 1$ enhances the antiproliferation and apoptosis inducing effect of Tet in HCT116 cells, which has been partly reversed by TGF- $\beta 1$ inhibitor. Tet decreases the phosphorylation of Akt1/2/3 in HCT116 cells. This effect can be enhanced by exogenous TGF- $\beta 1$, but partly reversed by TGF- $\beta 1$ inhibitor. Tet exhibits no effect on total level of PTEN, but decreases the phosphorylation of PTEN; exogenous TGF- $\beta 1$ enhances the effect of Tet on decreasing the phosphorylation of PTEN, which was partly reversed by TGF- $\beta 1$ inhibitor. Our findings suggested that Tet may be a promising candidate for colon cancer treatment, and the
\end{abstract}

Correspondence to: Professor Bai-Cheng He, Department of Pharmacology, School of Pharmacy, Chongqing Medical University, 1 Yixueyuan Road, Yuzhong, Chongqing 400016, P.R. China E-mail: 894704897@qq.com or hebaicheng99@yahoo.com

*Contributed equally

Key words: tetrandrine, colon cancer, anticancer, TGF- $\beta 1$, PI3K/Akt, PTEN anticancer activity may be mediated by inactivating PI3K/Akt signaling through upregulating TGF- $\beta 1$ to decrease the phosphorylation of PTEN.

\section{Introduction}

Colon cancer is one of the most common malignancies. In the last decades, the diagnosis and treatment for colon cancer have been improved greatly, especially with the screening at the early stage $(1,2)$. However, the prognosis is still far from satisfactory and the incidence of colon cancer is increasing, even though the targeted therapy agents have been introduced to clinic (3). The challenges for the treatment of colon cancer include the serious adverse effects of the traditional chemotherapy and the metastasis to disseminate the cancer cells to other organs or tissues. Therefore, there is still a great clinical need to provide new effective reagents for ameliorating the treatment of colon cancer.

The natural products or their derivate is one of the important sources for anticancer drugs (4). Multiple drugs from this source have been used for cancer treatment for a few decades, such as camptothecin (5), paclitaxel (6) and vincristine (7). Tetrandrine (Tet), an alkaloid of bisbenzylisoquinoline, originates from the dried root of herbal medicine Stephania tetrandra S. Moore (Chinese herb hang fang ji) (8). Tet possesses various pharmacological effects, so it can be used for anti-inflammatory, immunosuppression and anti-hypertension (9-11). Tet has essential anticancer effects in prostate cancer, lung cancer, bladder cancer, gastric and colon cancer $(8,12-15)$. It has been reported that several signaling pathways or critical factors have been involved in this activity, such as inhibition of PI3K/Akt, ERK and induction of p53 (16-18). Our previous study indicated that Tet can inhibit Wnt/ $\beta$-catenin signaling in human colon cancer cells $(14,19)$. However, the detail molecular mechanism remains unclear.

The transforming growth factor $\beta$ (TGF- $\beta$ ) is a superfamily, which plays an important role in regulating many 
cellular physiological processes, such as proliferation, differentiation, apoptosis and other functions (20). TGF- $\beta$ functions as ligand binding to the type II receptor, which recruits and phosphorylates the type I receptor. The phosphorylated type I receptor then phosphorylates the receptor-regulated SMADs (R-SMADs), and then the R-Smads binds with the coSmad (SMAD4).

The R-Smad/coSmad complexes translocate to the nucleus where they act as transcriptional factors to regulate the expression of downstream targets (20). Therefore, the appropriate TGF- $\beta$ signaling is critical for the maintenance of homeostasis (21). Three sub-types of TGF- $\beta$ are found in this family, including TGF- $\beta 1$, TGF- $\beta 2$ and TGF- $\beta 3$. In reference to cancer, all the three isoforms of TGF- $\beta$ are involved in cancer progression (22-24). For colon cancer, the dysfunction or loss of TGF- $\beta$ signaling will promote progression of cancer $(25,26)$. Although TGF- $\beta 1$ has been demonstrated to be associated with colon cancer (27), its role in colon cancer remains controversial. It can promote or suppress the growth of colon cancer cells. These may be dependent on the microenvironment, or have genetic defects (28). Evidence indicated that Tet may be a powerful anticancer agent for colon cancer treatment $(14,19)$. It has been reported that Tet can inhibit the transcription of TGF- $\beta 1$ to suppress the reproductive activity of cells (29). To date, it remains unclear whether TGF- $\beta 1$ is associated with the anticancer activity of Tet in colon cancer.

In this investigation, we studied the effect of Tet on TGF- $\beta 1$ in HCT116 cells, to evaluate the effect of TGF- $\beta 1$ on the anticancer activity of Tet. We found that Tet can substantially upregulate TGF- $\beta 1$ in HCT116 cells, and TGF- $\beta 1$ may mediate the anti-proliferation activity of Tet through inactivating PI3K/Akt signaling partly.

\section{Materials and methods}

Chemicals and drug preparations. Tetrandrine (Tet) was from Hao-xuan Bio-tech (Xi'an, China). The HCT116 cells was purchased from American Type Culture Collection (ATCC, Manassas, VA, USA). All primary antibodies were purchased from Santa Cruz Biotechnology, Inc. (Santa Cruz, CA, USA). LY294002 and LY364947 was from Targetmol Co., Ltd. (Shanghai, China). Cells were maintained in Dulbecco's modified Eagle's medium (DMEM) with $10 \%$ fetal bovine serum (FBS), $100 \mathrm{U} / \mathrm{ml}$ of penicillin and $100 \mu \mathrm{g} / \mathrm{ml}$ of streptomycin at $37^{\circ} \mathrm{C}$ and $5 \% \mathrm{CO}_{2}$.

Recombinant adenoviral constructs for TGF- $\beta 1, G F P$ and siRNA for PTEN. The recombinant adenovirual vectors were constructed following the AdEasy system (30). Briefly, the coding sequence (CDS) of human TGF- $\beta 1$ and green fluorescent protein (GFP) were amplified, the siRNA fragments for PTEN knockdown was synthesized commercially. These fragments were cloned into the shuttle vector pAdTrace, respectively. Then, the shuttle vectors were linearized and transfected into HEK293 cells for the package of the recombinant adenoviruses, which were designated as AdTGF- $\beta 1$ and AdsiPTEN. The recombinant adenoviruses mediated the over-expression were tagged with green GFP or red fluorescent protein (RFP) for knockdown to track the viruses, and the recombinant adenovirus expressing GFP (AdGFP) only was used as vehicle control.

Cell viability assay. The cell viability was determined with Cell Counting Kit-8 (CCK-8). In brief, HCT116 cells were seeded in 96-well plates with a density of $3 \times 10^{3}$ cells/well. Then, the cells were treated with different concentrations of Tet, recombinant adenovirus or DMSO for 24,48 and $72 \mathrm{~h}$. At the scheduled time-point, $10 \mu \mathrm{l}$ of CCK- 8 was added into each well and incubated for $4 \mathrm{~h}$. The absorbance was determined at $450 \mathrm{~nm}$ with an microplate reader. Each test was conducted in triplicate.

Clonogenic assay. The clonogenic assay was introduced to determine the ability of cells to undergo unlimited division and form colonies in a given population. Briefly, cells were pre-treated with different concentrations of Tet for $24 \mathrm{~h}$, and then re-plated the cells to 12 -well plates with a density of 2000 or 200 cells per well. Cells were maintained without Tet treatment up to 14 days until the colonies were formed. Finally, the plates were gently washed with PBS and incubated with $0.25 \%$ crystal violet formalin solution at room temperature for $20 \mathrm{~min}$, and finally washed with tap water and air-dried. The assay was conducted in triplicate independently.

Flow cytometric analysis for cell cycle and apoptosis. Cells were seeded in 6-well plates and treated with different concentrations of Tet for $48 \mathrm{~h}$. For cell cycle analysis, cells were harvested and washed with phosphate buffered saline (PBS, $\left.4^{\circ} \mathrm{C}\right)$, fixed with cold $\left(4^{\circ} \mathrm{C}\right) 70 \%$ ethanol, washed with $50 \%$ and $30 \%$ ethanol, and PBS. Finally, cells were stained with $1 \mathrm{ml}$ of propidium iodide (PI, $20 \mathrm{mg} / \mathrm{ml}$ ) containing RNase $(1 \mathrm{mg} / \mathrm{ml})$ in PBS for $30 \mathrm{~min}$, followed by flow cytometry analysis. For apoptosis analysis, cells were harvested and washed with PBS $\left(4^{\circ} \mathrm{C}\right)$, followed by incubating with Annexin V-EGFP (\#KGA104, KeyGen Biotech, Nanjing, China) and PI. Finally, the cells were analyzed with fluorescence activated cell sorting (FACS). Each assay was done in triplicate.

Reverse transcription (RT) and real-time polymerase chain reaction (PCR) analysis. The cells were plated in T25 flask and treated with different concentration of Tet. At the scheduled time-point, total RNA were extracted with TRIzol reagent (Invitrogen), and followed by RT reaction to generate cDNA. Then, the cDNA products were used as templates for real-time PCR to detect the expression level of target genes. The data of each sample were normalized with the corresponding expression level of glyceraldehyde-3-phosphate dehydrogenase (GAPDH). The primer sequences for this investigation are presented in Table I.

Western blot assay. Sub-confluent HCT116 cells were seeded in 6-well plates, and then treated with different concentrations of Tet and/or combined with corresponding recombinant adenovirus. At the scheduled time point, cell lysates were collected and boiled for $10 \mathrm{~min}$. All samples were subjected to electrophoresis with SDS-PAGE and transfered to polyvinylidene fluoride membranes, blotted with primary antibodies and corresponding secondary antibodies conjugated with horseradish peroxidase successively. Finally, the target bands were 
A

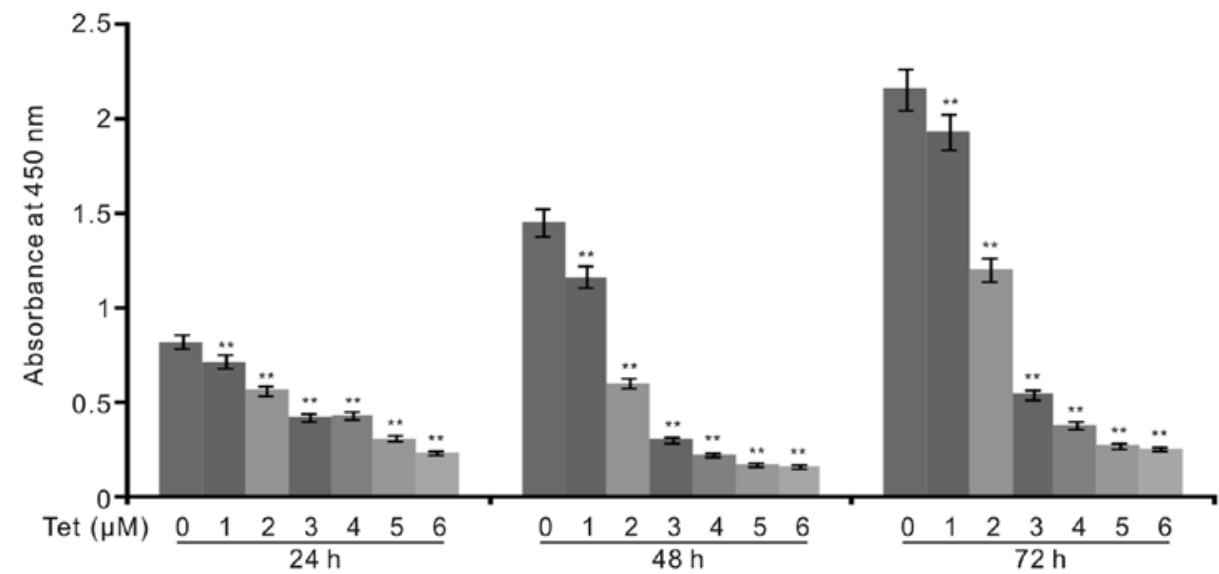

B

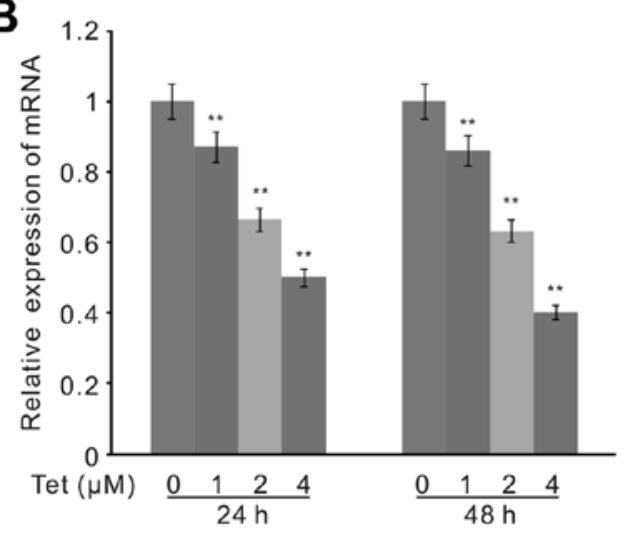

D

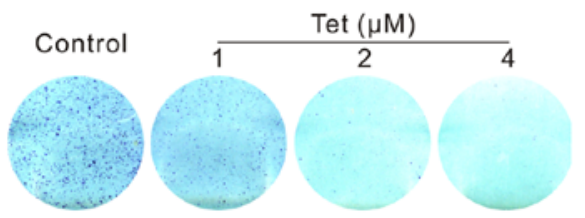

C

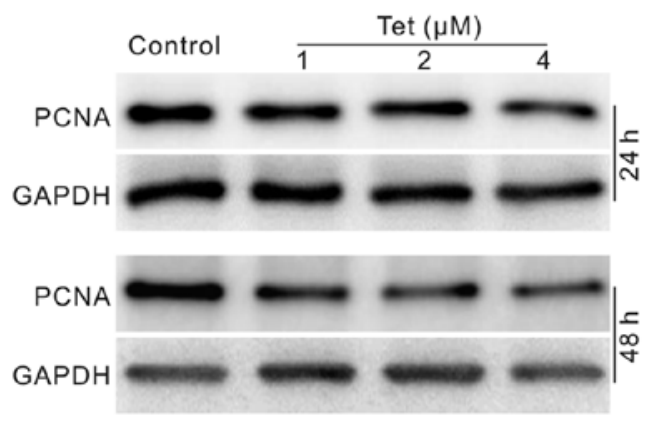

$\mathbf{E}$

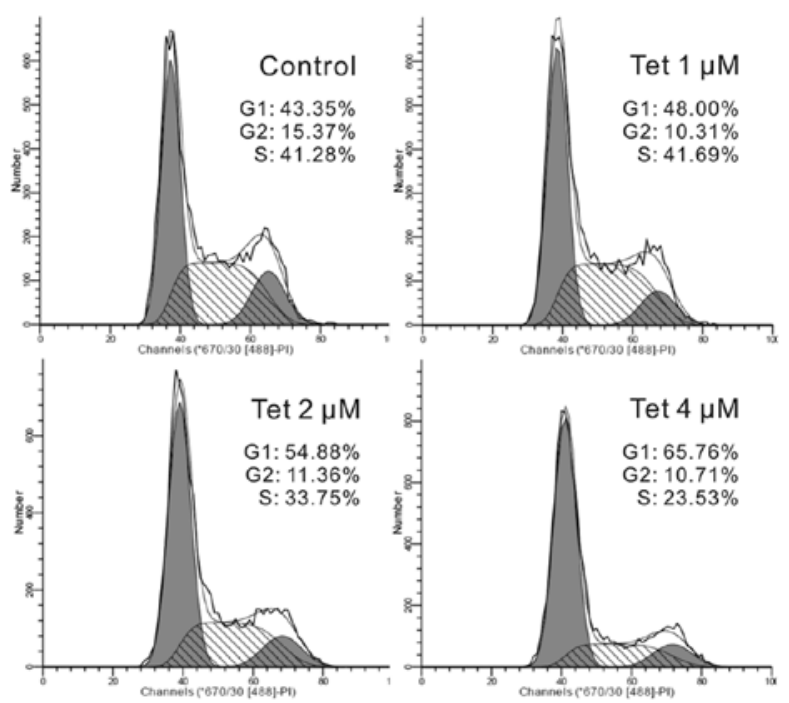

Figure 1. Effects of Tet on the proliferation of HCT116 cells. (A) CCK- 8 assay results show the effect of Tet on the proliferation of HCT116 cells $\left({ }^{* *} \mathrm{P}<0.01\right.$ vs. control). (B) Real-time PCR analysis results show the effect of Tet on the mRNA expression of PCNA in HCT116 cells ( ${ }^{* *} \mathrm{P}<0.01$ vs. control). (C) Western blot assay results show the effect of Tet on the protein level of PCNA. (D) Crystal violet staining of clonogenic formation results show the effect of Tet on the proliferation ability of HCT116 cells. (E) The results of flow cytometry analysis show the effect of Tet on the cell cycle arrest in HCT116 cells.

developed with SuperSignal West Femto Substrate (\#34095, Thermo Scientific, Rockford, IL, USA). Each assay was done in triplicate.

Immunocytochemical staining. Cells were plated into 48-well plates and treated as the experimental design. At the scheduled time point, cells were fixed with cold $\left(4^{\circ} \mathrm{C}\right)$ methanol for 15 min, and washed with cold PBS and permeablized with
$0.5 \%$ Triton X-100. Cells were blocked with 5\% BSA at room temperature for $1 \mathrm{~h}$, followed by incubation with p-Akt1/2/3, or PTEN antibody, the corresponding IgG were used as control, followed by incubation with rhodamine conjugated corresponding secondary antibodies for $30 \mathrm{~min}$. Finally, cells were stained with DAPI $(1 \mu \mathrm{g} / \mathrm{ml})$. The fluorescence images were recorded under an inverted microscope. Each assay was done in triplicate. 

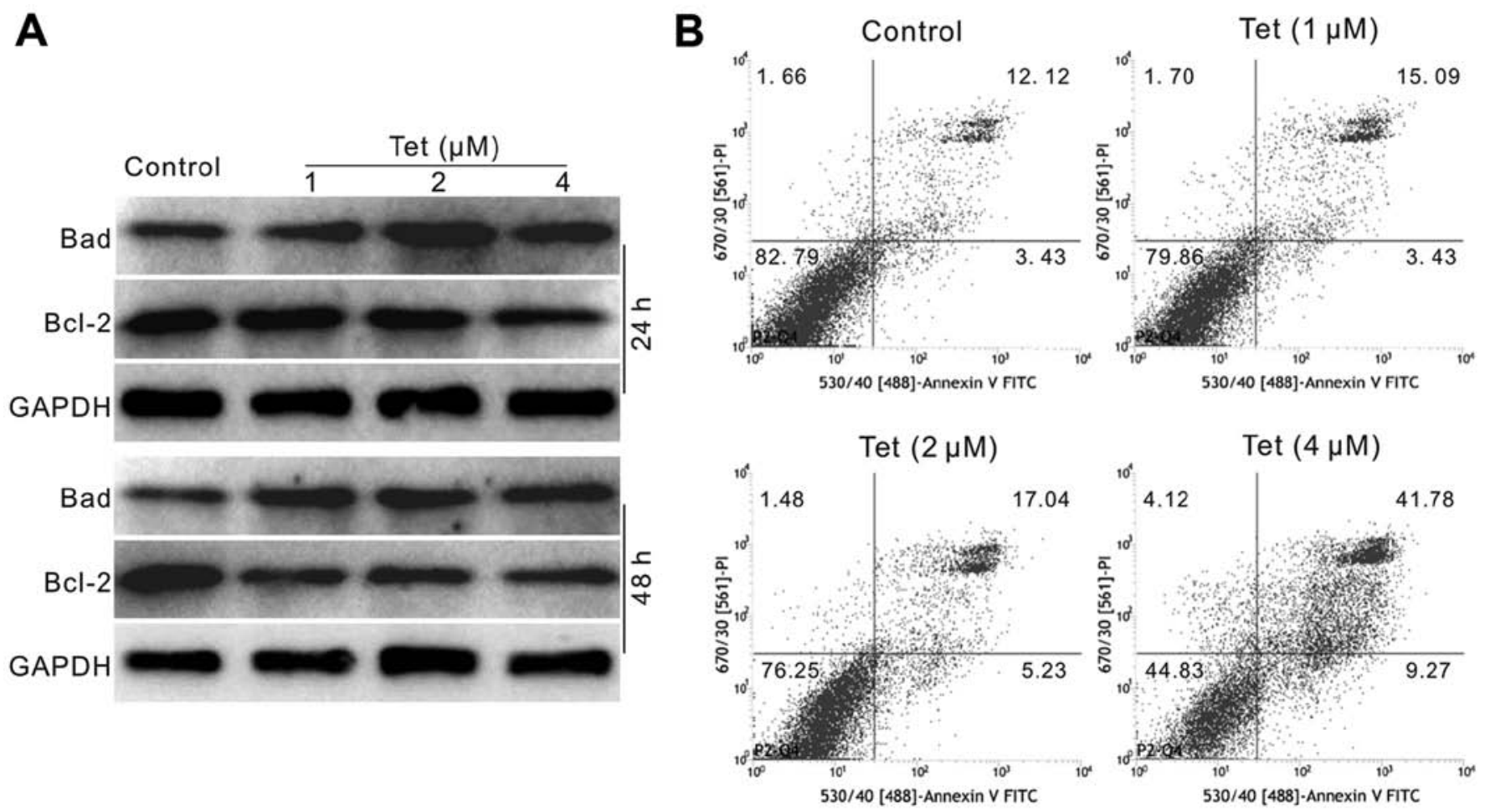

Figure 2. Effects of Tet on the apoptosis of HCT116 cells. (A) Western blot assay results show the effect of Tet on the protein level of Bad and Bcl-2 in HCT116 cells. (B) Flow cytometery analysis results show the effect of Tet on apoptosis in HCT116 cells.

Statistical analysis. Microsoft Excel was employed to calculate the standard deviations. The differences were analyzed using the Student's t-test.

\section{Results}

Effects of Tet on the proliferation of HCT116 cells. Tet has been shown to have powerful anticancer activity in various types of cancer cells. In this study, we tested the function of Tet in human colon cancer cell line HCT116. The CCK-8 assay results revealed that Tet can inhibit the proliferation of HCT116 cells concentration-dependently (Fig. 1A). The PCR assay results showed that the expression of PCNA was decreased substantially by the treatment of Tet (Fig. 1B), and western blot analysis results recaptured the same effect of Tet on PCNA in HCT116 cells (Fig. 1C). The colony formation assays demonstrated that the proliferation ability of HCT116 cells was greatly reduced by Tet (Fig. 1D). Finally, we introduced flow cytometry analysis to determine the effect of Tet on the cell cycle. The results showed that Tet arrested the cell cycle at G1 phase and obviously reduced the percentage of S phase in HCT116 cells (Fig. 1E). These data suggested that Tet can effectively suppress the proliferation of HCT116 cells.

Effects of Tet on apoptosis in HCT116 cells. As apoptosisinducing is one of the important properties of drugs for chemotherapy to show the anticancer activity, we next investigated the effect of Tet on the apoptosis in HCT116 cells. Western blot assay results showed that Tet decreases the level of Bcl-2, but increases the level of Bad in HCT116 cells (Fig. 2A). The flow cytometric analysis results showed that Tet increases the percentage of apoptotic cells in HCT116 cells (Fig. 2B). These results suggested that Tet may be an effective apoptosis inducer for cancer cells.

Effects of Tet on the expression of TGF- $\beta 1$ in HCT116 cells. The above data demonstrated that Tet can effectively suppress the growth and induce apoptosis in HCT116 cells, but the specific molecular mechanisms corresponding to these effects remains unclear. TGF- $\beta$ has been reported to be involved in the cause of colon cancer $(24,26)$. Therefore, TGF- $\beta$ may be one of the potential candidate targets for colon cancer treatment, although its role in colon cancer remains unclear. Hence, we detected the endogenous expression of the three sub-types of TGF- $\beta$ in the available colon cancer cell lines and FHC cells. PCR results showed that the expression level of TGF- $\beta 1$ is higher than that of TGF- $\beta 2$ and TGF- $\beta 3$ in these cells (Fig. 3A). As reports showed that TGF- $\beta 1$ and TGF- $\beta 3$ were related with colon cancer $(24,27)$, we checked the endogenous protein level of these two types of TGF- $\beta$, the results showed that both the protein of TGF- $\beta 1$ and TGF- $\beta 3$ are detectable in these cells, and the level of TGF- $\beta 1$ in FHC cells is much lower than that of TGF- $\beta 3$. However, the protein level of TGF- $\beta 1$ in cancer cells is much higher than that of FHC cells (Fig. 3B). These data may imply that TGF- $\beta 1$ is more associated with colon cancer cells. Hence, we focus on TGF- $\beta 1$ in the following experiments. Firstly, we checked the effect of Tet on the mRNA expression of TGF- $\beta 1$ in HCT116 cells. The results showed that Tet greatly increases the expression of TGF- $\beta 1$ (Fig. 3C). Western blot assay confirmed that Tet increases the level of TGF- $\beta 1$ obviously in HCT116 cells (Fig. 3D). These data implied that TGF- $\beta 1$ may be involved in the anticancer activity of Tet in HCT116 cells. 

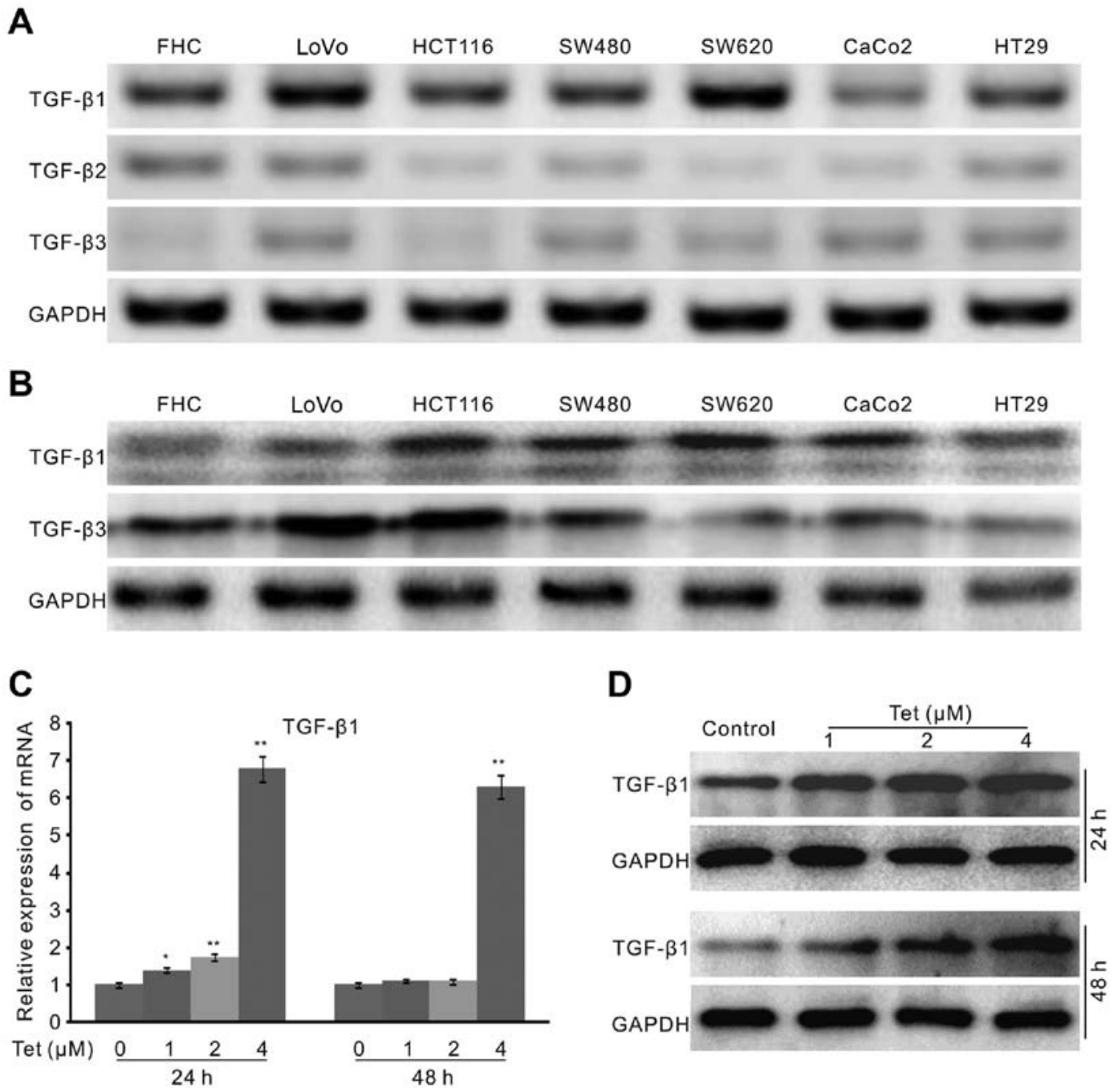

Figure 3. Effects of Tet on the expression of TGF- $\beta$ in HCT116 cells. (A) PCR results show the endogenous expression level of the three isoforms of TGF- $\beta$ in the available colon cancer cell lines and FHC cells. GAPDH was used as loading control. (B) Western blot assay results show the endogenous protein level of TGF- $\beta 1$ and TGF- $\beta 3$. (C) Real-time PCR results show the effect of Tet on the mRNA expression level of TGF- $\beta 1$ in HCT116 cells $\left({ }^{*} \mathrm{P}<0.05\right.$ vs. control; ${ }^{* *} \mathrm{P}<0.01$ vs. control). (D) Western blot assay results show the effect of Tet on the protein level of TGF- $\beta 1$ in HCT116 cells.

Table I. The primers used for PCR assay.

Gene $\quad$ Primer sequence (5'-3')

$\begin{array}{ll}\text { GAPDH } & \text { F: CAACGAATTTGGCTACAGCA } \\ & \text { R: AGGGGAGATTCAGTGTGGTG } \\ \text { PCNA } & \text { F: GGCTCTAGCCTGACAAATGC } \\ & \text { R: GCCTCCAACACCTTCTTGAG } \\ \text { TGF- } \beta 1 & \text { F: CCCACAACGAAATCTATGACAA } \\ & \text { R: AAGATAACCACTCTGGCGAGTC } \\ \text { TGF- } \beta 2 & \text { F: ACTACGCCAAGGAGGTTTACAA } \\ & \text { R: TCTGAACTCTGCTTTCACCAAA } \\ \text { TGF- } \beta 3 & \text { F: TGGTTAGAGGAAGGCTGAACTC } \\ & \text { R: ATGAGCAAATCCAACCTCAGAT } \\ \text { PTEN } & \text { F: TAAAGGCACAAGAGGCCCTA } \\ & \text { R: CGCCACTGAACATTGGAATA }\end{array}$

F, forward; R, reverse.
Effects of TGF- $\beta 1$ on the anti-proliferation and apoposisinducing effect of Tet in HCT116 cells. As Tet greatly increases the level of TGF- $\beta 1$ in colon cancer cells and the endogenous level of TGF- $\beta 1$ in colon cancer cells is much higher than that of FHC cells, we next investigated the effect of TGF- $\beta 1$ on the anticancer activity of Tet in HCT116 cells. We introduced the recombinant adenovirus to mediate the exogenous expression of TGF- $\beta 1$, and specific inhibitor to block the TGF- $\beta 1$ signaling. The results showed that the exogenous TGF- $\beta 1$ partly reduces the survival and apparently potentiates the antiproliferation effect Tet in HCT116 cells, while the TGF- $\beta 1$ specific inhibitor increases the proliferation and partly reverses the anti-proliferation effect of Tet in HCT116 cells (Fig. 4A). Moreover, the exogenous TGF- $\beta 1$ increases the level of Tet-induced $\mathrm{Bad}$ and decreases the level of $\mathrm{Bcl}-2$ induced by Tet (Fig. 4B). The TGF- $\beta 1$ inhibitor apparently decreases the level of Tet-induced Bad, and increases the level of Bcl-2 which was decreased by Tet in HCT116 cells (Fig. 4C). These results suggested that TGF- $\beta 1$ may play an important role in mediating the anticancer activity of Tet in HCT116 cells, although the explicit mechanism underlying this effect remains unknown. 
A

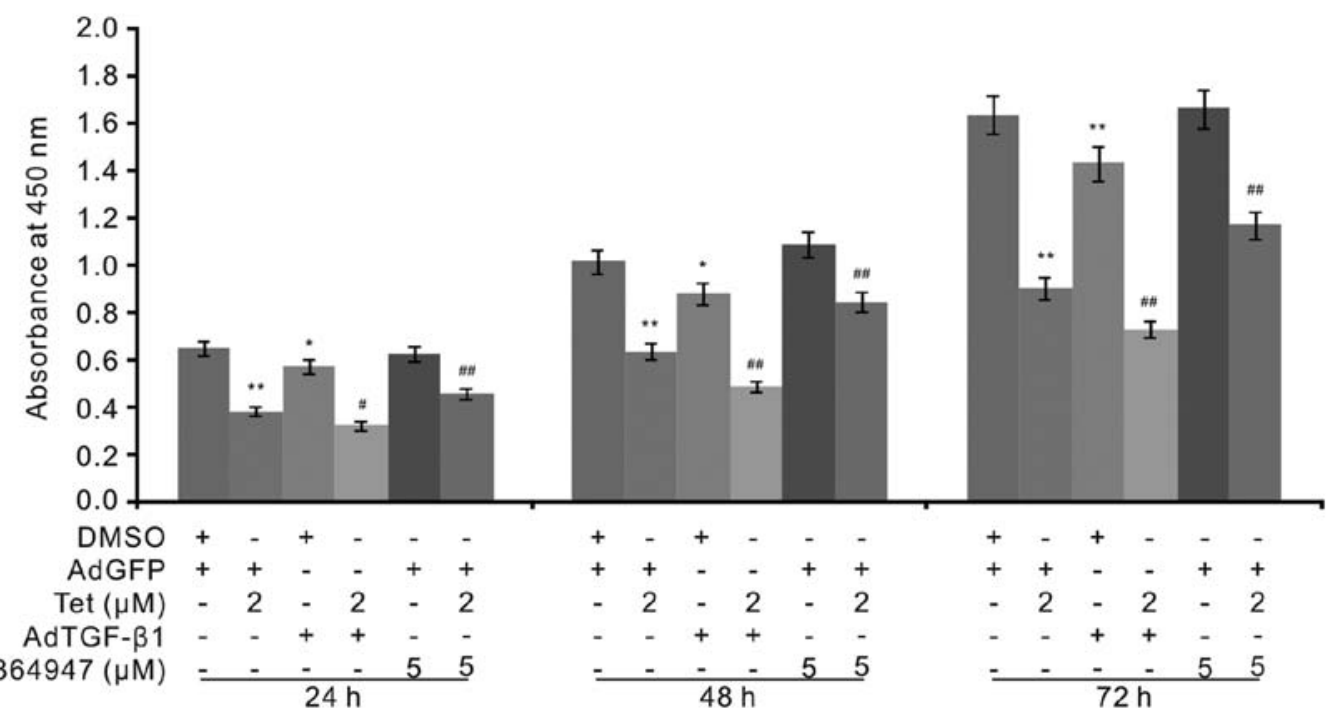

B
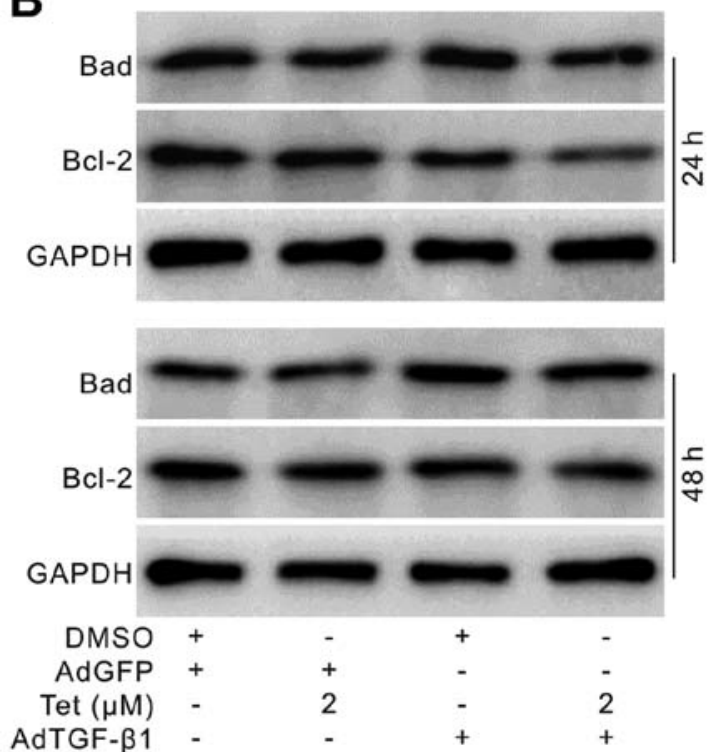

C
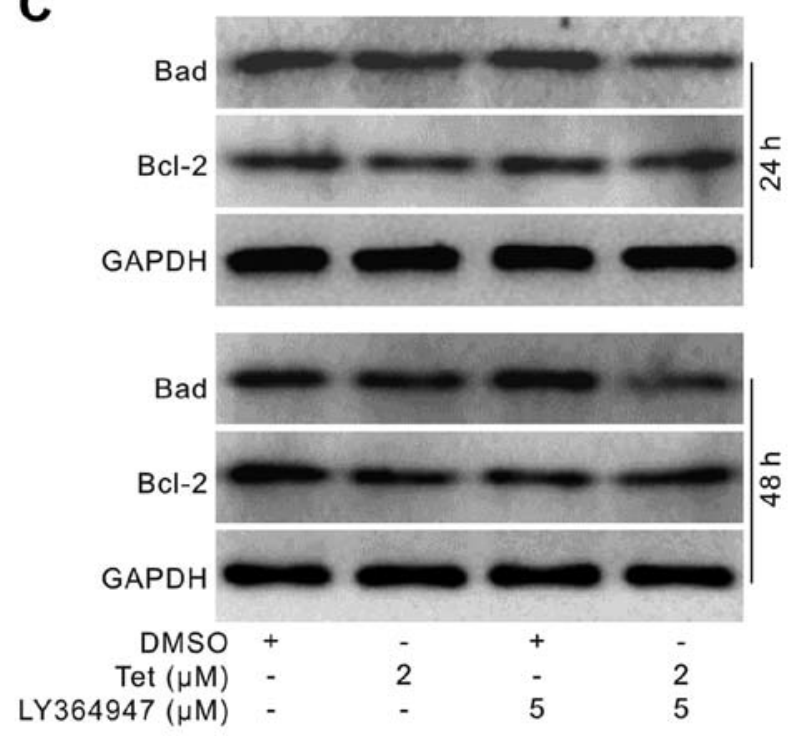

Figure 4. Effects of TGF- $\beta 1$ on the anticancer activity of Tet in HCT116 cells. (A) CCK- 8 assay results show the effect of TGF- $\beta 1$ on the anti-proliferation effect of Tet in HCT116 cells (LY364947, the inhibitor for TGF- $\beta 1$. ${ }^{*} \mathrm{P}<0.05$ vs. control; ${ }^{* *} \mathrm{P}<0.01$ vs. control; ${ }^{\#} \mathrm{P}<0.05$ vs. Tet treated group, ${ }^{\# \#} \mathrm{P}<0.01$ vs. Tet treated group). (B) Western blot assay results show the effect of exogenous expression of TGF- $\beta 1$ on the level of Bad and Bcl-2 affected by Tet in HCT116 cells. GAPDH was used as loading control. (C) Western blot assay results show the effect of TGF- $\beta 1$ inhibitor on the level of Bad and Bcl-2 affected by Tet in HCT116 cells. GAPDH was used as loading control.

Effects of TGF- $\beta 1$ on the PI3K/Akt signaling in HCT116 cells. TGF- $\beta 1$ ligand binding with type II receptor activate TGF- $\beta$ signaling, but our pilot tests demonstrated that Tet can not increase the phosphorylation of Smad2/3 (data are not shown). Hence, TGF- $\beta 1$ may mediate the anticancer effect of Tet through non-canonical TGF- $\beta$ signaling, such as PI3K/ Akt pathway. PI3K/Akt signaling is one of the essential pathways for the regulation of cell survival and differentiation, and drugs have been developed and targeted on this signaling to inhibit the proliferation of cancer cells. It has been reported that Tet can induce cell cycle arrest through inhibiting the PI3K/Akt pathway in HT29 cells (31). However, it is unclear whether the anti-proliferation effect of Tet in HCT116 cells can also be mediated through downregulating this pathway. Hence, we determined the effect of Tet on PI3K/Akt pathway in HCT116 cells. Western blot analysis showed that Tet markedly reduces the level of phosphorylated Akt1/2/3 (p-Akt1/2/3), although no obvious effect was seen on the total level of Akt1/2 (Fig. 5A). The CCK-8 assay results showed that $\mathrm{PI} 3 \mathrm{~K}$ inhibitor markedly potentiates the anti-proliferation effect of Tet in HCT116 cells (Fig. 5B). These data indicated that the anti-proliferation effect of Tet in HCT116 cells may be mediated through the inactivation of PI3K/Akt signaling, but how Tet suppresses this pathway remains unclear. As Tet substantially increases the level of TGF- $\beta 1$ in HCT116 cells, we speculated that the inactivation of PI3K/Akt signaling by Tet may be associated with the Tet-induced increase of TGF- $\beta 1$ in HCT116 cells.

Western blot assay showed that exogenous TGF- $\beta 1$ promotes the effect of Tet by decreasing the level of $\mathrm{p}-\mathrm{Akt} 1 / 2 / 3$ 
A
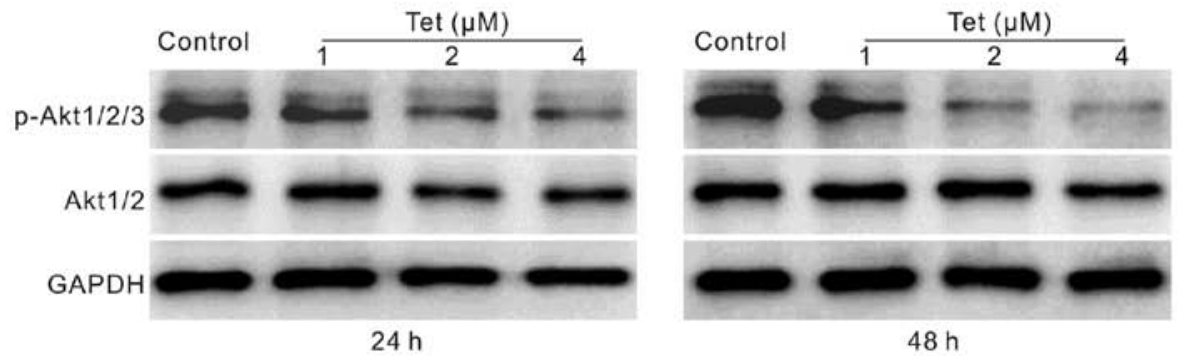

B

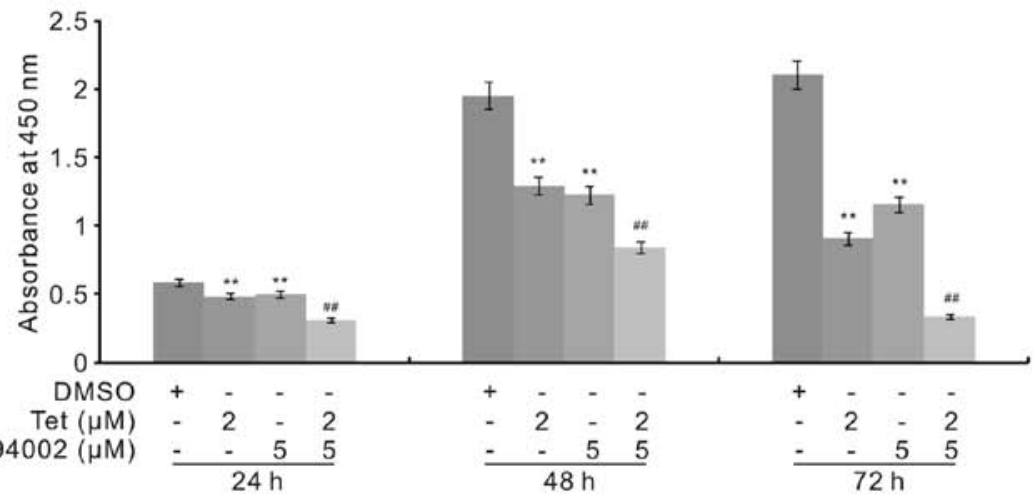

C

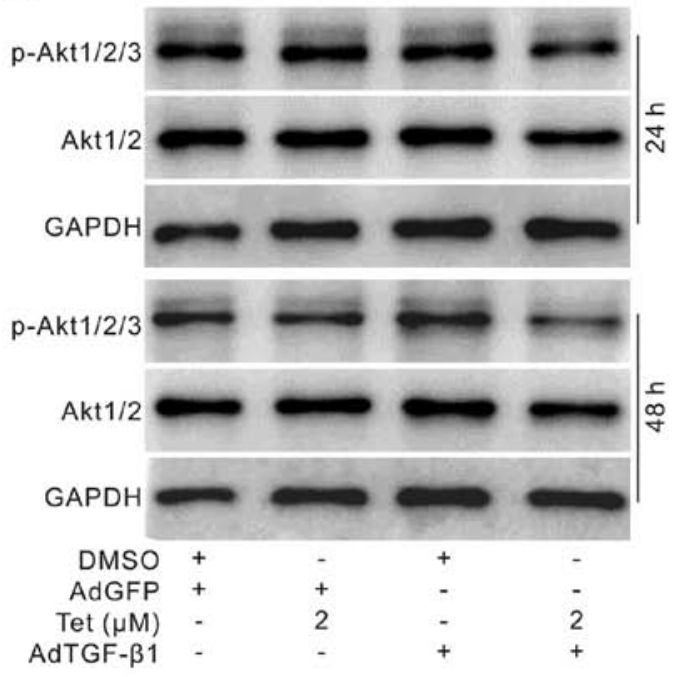

D

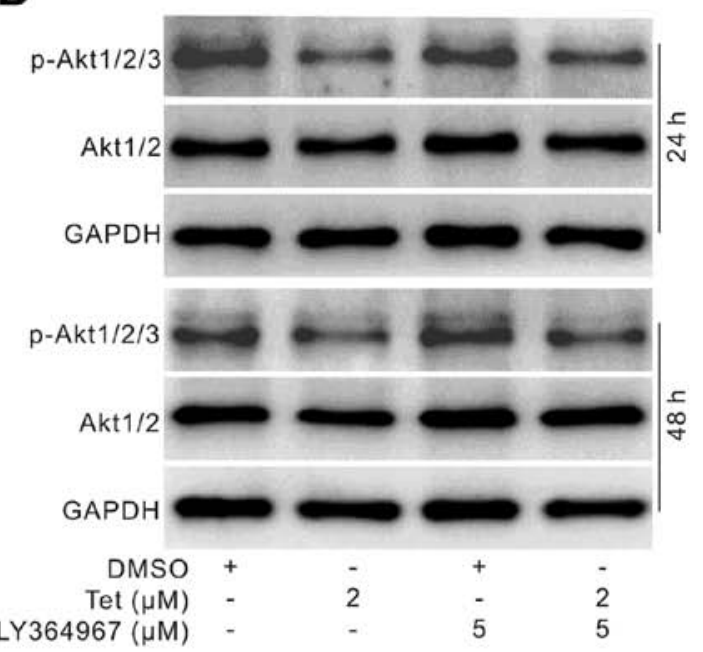

\section{$\mathbf{E}$}

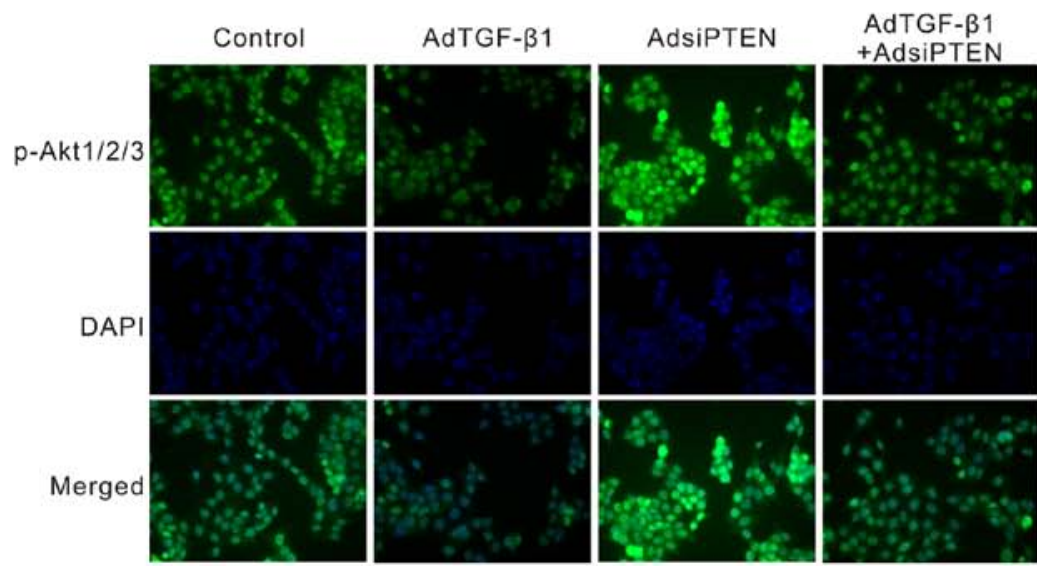

Figure 5. Effects of Tet and TGF- $\beta 1$ on the activation of PI3K/Akt pathway in HCT116 cells. (A) Western blot assay shows the effect of Tet on the total level of Akt1/2 and phosphorylated Akt1/2/3 (p-Akt1/2/3) in HCT116 cells. GAPDH was used as loading control. (B) CCK-8 assay results show the effect of PI3K inhibitor on the anti-proliferation effect of Tet in HCT116 cells (LY294002, the inhibitor for PI3K. ${ }^{* *} \mathrm{P}<0.01$ vs. control; ${ }^{\# \#} \mathrm{P}<0.01$ vs. Tet treated group). (C) Western blot assay results show the effect of exogenous expression of TGF- $\beta 1$ on the level of Akt1/2 and p-Akt1/2/3 affected by Tet in HCT116 cells. GAPDH was used as loading control. (D) Western blot assay results show the effect of TGF- $\beta 1$ inhibitor on the level of Akt1/2 and p-Akt1/2/3 affected by Tet in HCT116 cells. GAPDH was used as loading control. LY364947, the inhibitor for TGF- $\beta 1$. (E) Immunofluorescent stain results show the effect of exogenous expression of TGF- $\beta 1$ and/or knockdown of PTEN on the level of p-Akt1/2/3 in HCT116 cells. 
but no obvious effect on the level of total Akt1/2 (Fig. 5C). The TGF- $\beta 1$ inhibitor increases the level of $p-A k t 1 / 2 / 3$ and partly reverses the Tet-induced decrease of p-Akt1/2/3 (Fig. 5D). In order to confirm the effect of TGF- $\beta 1$ on the p-Akt $1 / 2 / 3$ in HCT116 cells, we constructed the recombinant adenovirus for siRNA fragments of PTEN, a well-known negative regulator for PI3K/Akt signaling. The immunofluorescence staining results showed that knockdown of PTEN greatly increases the level of $\mathrm{p}-\mathrm{Akt} 1 / 2 / 3$, but this effect can be thoroughly eliminated by the exogenous TGF- $\beta 1$ in HCT116 cells (Fig. 5E). All these data suggested that the anti-proliferation effect of Tet in HCT116 cells may be mediated by inactivating PI3K/Akt signaling through upregulating the expression of TGF- $\beta 1$.

Effects of TGF- $\beta 1$ on the PTEN affected by Tet in HCT116 cells. PI3K/Akt signaling is finely regulated by various factors, one of which is PTEN. PTEN dephosphorylates PIP3 to form PIP2, which makes the inactivation of PI3K/Akt signaling. The above mentioned data showed that Tet decreases the level of p-Akt1/2/3 in HCT116 cells, which may be mediated by upregulating TGF- $\beta 1$. As PTEN is a critical negative regulator for PI3K/Akt signaling, it implied that the effect TGF- $\beta 1$ on PI3K/Akt signaling may result from the upregulation of PTEN in HCT116 cells. With this hypothesis, we determined the effect of TGF- $\beta 1$ on PTEN and phosphorylated PTEN (p-PTEN). The PCR assay results showed that Tet suppresses the mRNA expression of PTEN in HCT116 cells (Fig. 6A). However, western blot analysis results showed that Tet exerts no substantial effect on the total protein level of PTEN, but decreases the level of p-PTEN (Fig. 6B). The immunofluorescence staining results confirmed that Tet exerts no obvious effect on the level of PTEN in HCT116 cells (Fig. 6C). Further analysis showed that exogenous TGF- $\beta 1$ can partly decrease the level of p-PTEN and synergistically reduces the level of p-PTEN induced by Tet in HCT116 cells (Fig. 6D). However, the TGF- $\beta 1$ inhibitor increases the level of p-PTEN and partly reverses the Tet-induced decrease of p-PTEN (Fig. 6E). These data indicated that the upregulation of TGF- $\beta 1$ may mediate the anticancer effect of Tet in HCT116 cells through partly suppressing the phosphorylation of PTEN.

\section{Discussion}

Colon cancer is one of the leading malignancies in gastrointestinal system and the unsatisfactory prognosis need to be greatly ameliorated. Tet has been demonstrated as a powerful reagent with anticancer activity. We investigated the anticancer activity of Tet in HCT116 cells and found that the effect of Tet in colon cancer cells may be mediated by upregulating TGF- $\beta 1$ to inactivate the PI3K/Akt signaling through partly decreasing the phosphorylation of PTEN.

The treatment of colon cancer includes chemotherapy, and surgery. The prognosis remains undesirable even though the targeted therapy has been introduced to the clinic (3). The challenge for treatment of cancer includes the serious side effects of the traditional chemotherapy drugs, metastasis and the drug resistance of cancer cells. There is a great clinical need to explore new effective drugs for the treatment of colon cancer. Natural products or their derivates is one of the essential resources for anticancer drugs. With regard to colon cancer, camptothecin or its deriveate irinotecan have been clinically used for decades $(32,33)$. Tet is a plant-derived bisbenzylisoquinoline alkaloid, mostly extracted from the root of medicine herb Stephania tetrandra S Moore (8).

It is a well-know calcium blocker and possesses multipharmacological activities, so Tet can be used widely for the treatment of hypertension, asthma, tuberculosis, dysentery and hyperglycemia (34). Increasing evidence supports that Tet is also a potent anticancer reagent, it exhibits efficacious anticancer activity to many kinds of cancer cells, such as prostate cancer, lung cancer, bladder cancer, gastric and colon cancer $(8,12-15)$. Our previous study also suggested that Tet may be a chemotherapy and/or chemoprevention drug for colon cancer $(14,19)$. Consequently, Tet may be a promising anticancer candidate agent for colon cancer treatment. In terms of the mechanism, various targets have been reported to be related with the anticancer activity of Tet, such as the inhibition of Wnt/ $\beta$-catenin signaling, PI3K/Akt signaling, ERK and inducing p53 (16-19). So far, the specific molecular mechanism remains unclear, and further thorough investigation need to be carried out for unveiling this process.

TGF- $\beta$ super-family includes secreted proteins, such as TGF- $\beta$, bone morphogenetic proteins (BMPs), activins, and Nodal (35). These proteins act as ligand to bind with TGF- $\beta$ type II receptor, and followed by the activation of TGF- $\beta$ type I receptor. Finally, it interacts with different Smads to regulate multiple downstream targets, which are involved in a plethora of physiological processes. Therefore, the aberrant TGF- $\beta$ signaling has been referred to in many diseases $(36,37)$. For TGF- $\beta$, there are three isoforms, including TGF- $\beta 1$, TGF- $\beta 2$ and TGF- $\beta 3$, and they are all expressed in mammalian cells. The role of TGF- $\beta$ is still unclear in tumor initiation and progression, as it can act as a tumor suppressor or promoter (36). The dual role of TGF- $\beta$ may be context and stage of cancerdependent. In epithelial cells, TGF- $\beta$ usually functions as a tumor suppressor though inhibiting proliferation and inducing apoptosis; in other tissues, TGF- $\beta$ may promote the progression of cancer, such as increasing the invasion and metastasis of tumor cells (38).

TGF- $\beta$ may also suppress the tumor at the early stage and act as a promoter at the late stage (39). In term of colon cancer, TGF- $\beta 1$ has been reported to increase the progression of colon cancer by upregulating the expression of Human Cripto-1 (CR-1) (40), and promoting the migration of cancer cells (41). It remains unknown whether TGF- $\beta 1$ can also exert antiproliferation activity in colon cancer cells. Our previous study demonstrated the potential anti-proliferation effect of Tet in colon cancer $(14,19)$. It has been reported that Tet can decrease the mRNA level of TGF- $\beta 1$ in the nitrofen-induced congenital diaphragmatic hernia (42), but its effect on the expression of TGF- $\beta 1$ in cancer cells remains unclear.

In this study, we found that the isoforms of TGF- $\beta$ all are detectable in the colon cancer and FHC cells. However, the protein level of TGF- $\beta 1$ in FHC cells is much lower than any of the cancer cell lines. For TGF- $\beta 3$, its level in FHC cells are higher than that of other cancer cell lines. These data suggested that TGF- $\beta 1$ and TGF- $\beta 3$ may function differently for colon cancer. With PCR and western blot analysis we found that Tet can obviously increase the expression of TGF- $\beta 1$ in HCT116 


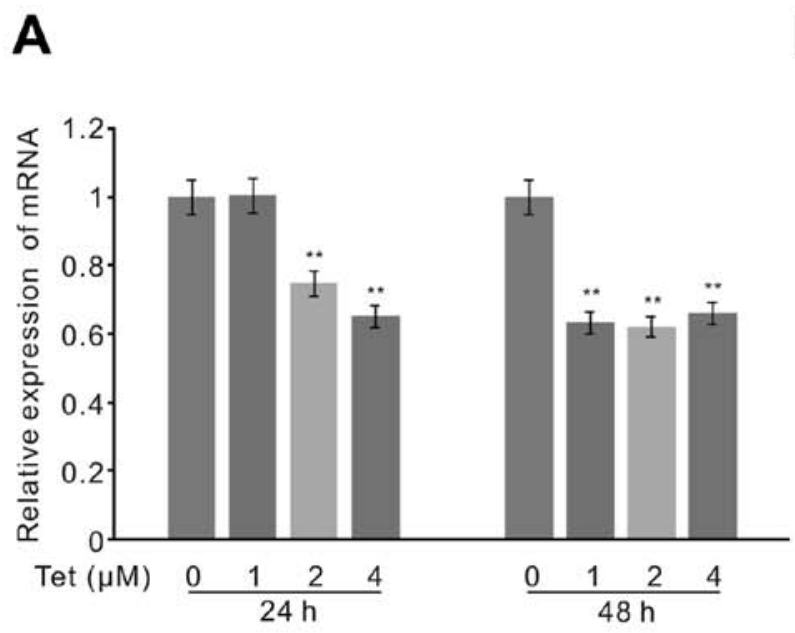

B

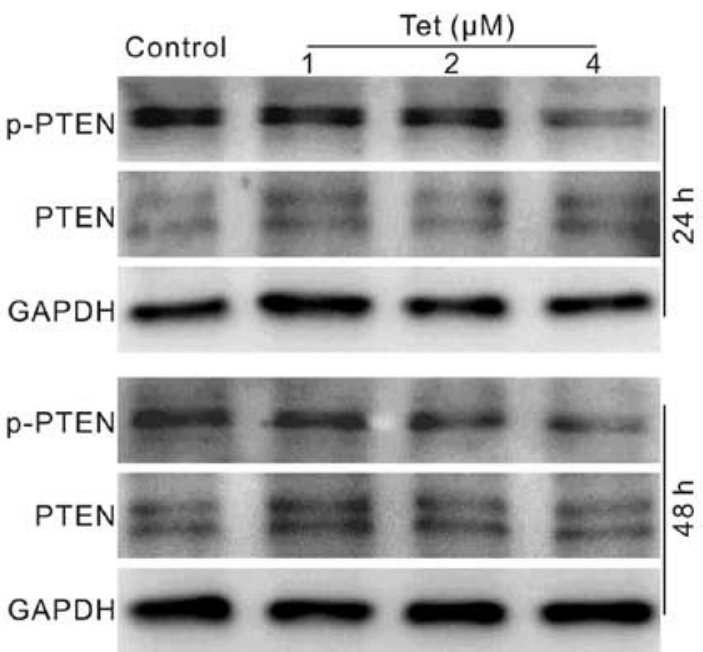

C
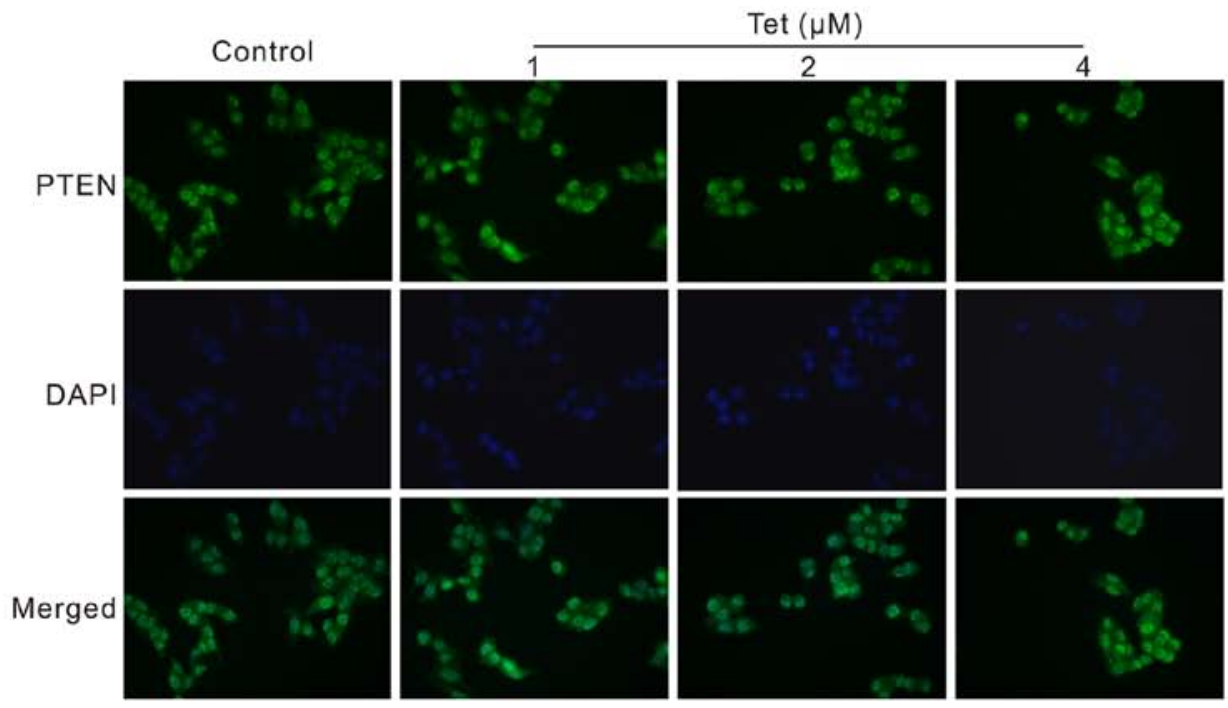

D

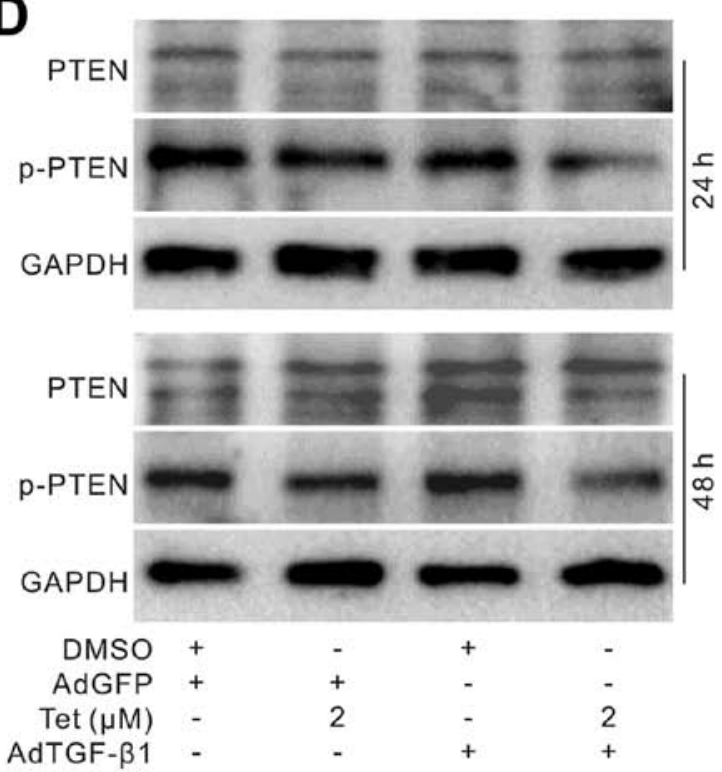

$\mathbf{E}$
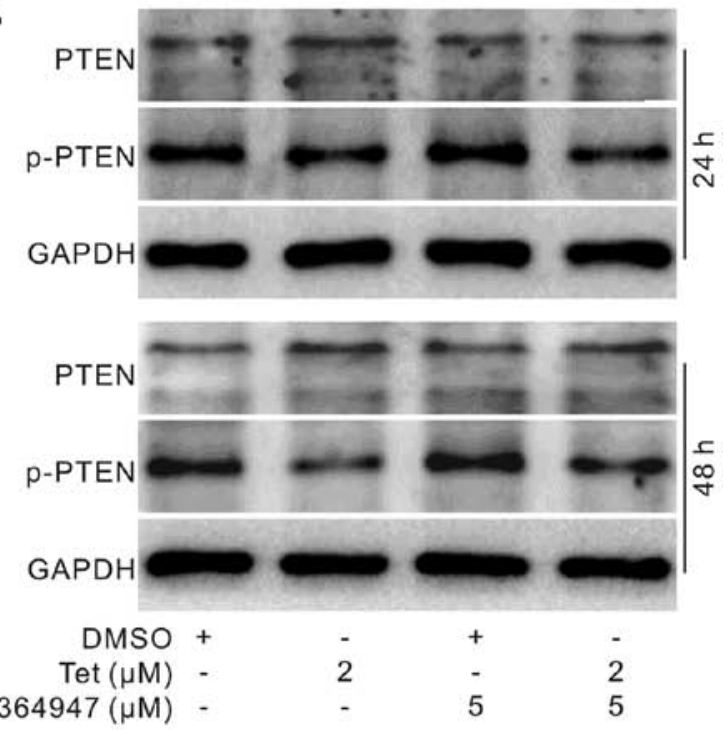

Figure 6. Effects of TGF- $\beta 1$ on the PTEN affected by Tet in HCT116 cells. (A) Real-time PCR assay results show the effect of Tet on the mRNA expression of PTEN in HCT116 cells ( $(*$ P $<0.01$ vs. control). (B) Western blot assay results show the effect of Tet on the total level of PTEN and phosphorylated PTEN (p-PTEN) in HCT116 cells. GAPDH was used as loading control. (C) Immunofluorescent stain results show the effect of Tet on the level of PTEN in HCT116 cells. (D) Western blot assay shows the effect of exogenous expression of TGF- $\beta 1$ on the level of PTEN and p-PTEN affected by Tet in HCT116 cells. GAPDH was used as loading control. (E) Western blot assay results show the effect of TGF- $\beta 1$ inhibitor on the level of PTEN and p-PTEN affected by Tet in HCT116 cells. GAPDH was used as loading control (LY364947, the inhibitor for TGF- $\beta 1$ ). 
cells. Hence, we speculated that the anti-proliferation activity of Tet in HCT116 cells may be associated with the upregulation of TGF- $\beta 1$. With further analysis, we found that exogenous expression of TGF- $\beta 1$ enhances the anti-proliferation effect of Tet, and TGF- $\beta 1$ inhibitor partly reverses the Tet-induced suppression of proliferation. Exogenous expression of TGF- $\beta 1$ enhances the effect of Tet on the increase of Bad and reduces Bcl-2. On the contrary, TGF- $\beta 1$ inhibitor decreases the effect of Tet on increasing the level of Bad and partly reverses the Tet-induced decrease of Bcl-2 in HCT116 cells. Herein, our data suggested that the anti-proliferation activity of Tet may be partly mediated by upregulating TGF- $\beta 1$ in HCT116 cells.

One of the important functions of TGF- $\beta$ is to regulate cell proliferation, apoptosis and differentiation through the canonical TGF- $\beta$ pathway, by binding with their receptor, or the non-canonical TGF- $\beta$ pathway, such as Wnt/ $\beta$-catenin and PI3K/Akt signaling. TGF- $\beta$ prevents osteogenic differentiation by inhibiting BMP and Wnt/ $\beta$-catenin signaling (43). TGF- $\beta$ has also been reported to active PI3K/Akt signaling to promote the migration and invasion of prostate cancer cells, and the differentiation of radial glia into astrocyte $(44,45)$. Our results demonstrated that Tet can not increase the phosphorylation of Smad2/3, instead of reducing it (data are not shown). Thus, TGF- $\beta 1$ may mediate the anti-proliferation effect of Tet through non-canonical TGF- $\beta$ signaling pathway. It was reported that Tet can inactivate PI3K/Akt signaling to induce cell cycle arrest and apoptosis in HT29 cells (31).

Our results indicated that Tet can also decrease the phosphorylation of Akt1/2/3 (p-Akt1/2/3) in HCT116 cells, although it did not exert any obvious effect on the total level of Akt1/2. Thus, it is possible for Tet to inactivate PI3K/Akt signaling through the upregulation of TGF- $\beta 1$ in HCT116 cells. Further analysis revealed that exogenous expression of TGF- $\beta 1$ potentiates the inhibitory effect of Tet on the level of $\mathrm{p}-\mathrm{Akt} 1 / 2 / 3$, while TGF- $\beta 1$ inhibitor partly reverses the Tet-induced decrease of $\mathrm{p}-\mathrm{Akt} 1 / 2 / 3$ in HCT 116 cells. Our data also showed that exogenous expression of TGF- $\beta 1$ substantially diminishes the level of $\mathrm{p}-\mathrm{Akt} 1 / 2 / 3$ induced by knockdown of the phosphatase and tensin homolog deleted on chromosome ten (PTEN) in HCT116 cells. Therefore, the evidence suggested that Tet may inhibit the phosphorylation of Akt $1 / 2 / 3$ through upregulating TGF- $\beta 1$ in colon cancer cells.

PTEN is a well-known tumor suppressor, as phosphatase negatively regulates the phosphatidylinositol-3-kinase (PI3K) signaling pathway by catalyzing phosphatidylinositol 3,4,5-triphosphate (PIP3) dephosphorylates to PI-4,5bisphosphate (PIP2). The PI3K/Akt signaling is critical for cell survival and differentiation. Accordingly, the dysfunction of PTEN will make the PI3K/Akt signaling over-activated and the cell growth out of control. Therefore, it is also considered as the potential target for cancer treatment (46). Various factors may lead to the function loss of PTEN, such as inherited mutations, epigenetic and/or transcriptional silence, and post-transcriptional modification (47). In colon cancer, the dysfunction of PTEN, may result from genetic and/or epigenetic changes, and is one of the main causes for the initiation and progression of cancer (48). PTEN may be used as a prognostic and predictive factor for colon cancer, and a target for the treatment of colon cancer. In this study, we demonstrated that Tet decreases the phosphorylation of Akt1/2/3 in HCT116 cells from upregulating TGF- $\beta 1$. Thus, we speculated that this effect of TGF- $\beta 1$ on the phosphorylation of Akt1/2/3 may result from the regulation of PTEN. With PCR, we found that Tet decreases the mRNA expression of PTEN rather than increasing it. However, western blot assay results showed that Tet substantially decreases the phosphorylation level of PTEN, although has no obvious effect on the total level of PTEN. Exogenous expression of TGF- $\beta 1$ increases the inhibitory effect of Tet on the phosphorylation of PTEN (p-PTEN), but the TGF- $\beta 1$ inhibitor promotes the phosphorylation of PTEN and partly reverses the Tet-induced decrease of p-PTEN. However, how TGF- $\beta 1$ regulates the phorphorylation of PTEN need to be further elucidated.

Taken together, our data strongly suggested that Tet may be a potential candidate for colon cancer treatment. The anticancer activity of Tet in HCT116 cells may be partly mediated by upregulating the expression of TGF- $\beta 1$, which may inactivate the PI3K/Akt signaling through partly decreasing the phosphorylation of PTEN.

\section{Acknowledgements}

We would like to thank Professor T.C. He of the University of Chicago Medical Center (Chicago, IL, USA) for his kind provision of the recombinant adenoviruses. This work was supported by research grant from Chongqing Science and Technology Commision (grant no. cstc2015jcyjA10046 to K.W.) and the National Natural Science Foundation of China (grant no. NSFC 81372120 to B.-C.H.).

\section{References}

1. Winder T and Lenz HJ: Molecular predictive and prognostic markers in colon cancer. Cancer Treat Rev 36: 550-556, 2010.

2. Anderson JC and Shaw RD: Update on colon cancer screening: Recent advances and observations in colorectal cancer screening. Curr Gastroenterol Rep 16: 403, 2014.

3. Karanikas $M$ and Esebidis A: Increasing incidence of colon cancer in patients $<50$ years old: A new entity? Ann Transl Med 4: 164, 2016.

4. Dinic J, Podolski-Renic A, Stankovic T, Bankovic J and Pesic M: New approaches with natural product drugs for overcoming multidrug resistance in cancer. Curr Pharm Des 21: 5589-5604, 2015.

5. Chazin EL, Reis RR, Junior WT, Moor LF and Vasconcelos TR: An overview on the development of new potentially active camptothecin analogs against cancer. Mini Rev Med Chem 14: 953-962, 2014.

6. Baird RD, Tan DS and Kaye SB: Weekly paclitaxel in the treatment of recurrent ovarian cancer. Nat Rev Clin Oncol 7: 575-582, 2010.

7. Xie X, Tang B, Zhou J, Gao Q and Zhang P: Inhibition of the PI3K/Akt pathway increases the chemosensitivity of gastric cancer to vincristine. Oncol Rep 30: 773-782, 2013.

8. Qin R, Shen H, Cao Y, Fang Y, Li H, Chen Q and Xu W: Tetrandrine induces mitochondria-mediated apoptosis in human gastric cancer BGC-823 cells. PLoS One 8: e76486, 2013.

9. Lin YC, Chang CW and Wu CR: Anti-nociceptive, anti-inflammatory and toxicological evaluation of Fang-Ji-Huang-Qi-Tang in rodents. BMC Complement Altern Med 15: 10, 2015.

10. Ho LJ, Juan TY, Chao P, Wu WL, Chang DM, Chang SY and Lai JH: Plant alkaloid tetrandrine downregulates IkappaBalpha kinases-IkappaBalpha-NF-kappaB signaling pathway in human peripheral blood T cell. Br J Pharmacol 143: 919-927, 2004.

11. Zhang J, Yu B, Zhang XQ, Sheng ZF, Li SJ, Wang ZJ, Cui XY, Cui SY and Zhang YH: Tetrandrine, an antihypertensive alkaloid, improves the sleep state of spontaneously hypertensive rats (SHRs). J Ethnopharmacol 151: 729-732, 2014. 
12. Kou B, Liu W, He W, Zhang Y, Zheng J, Yan Y, Zhang Y, Xu S and Wang H: Tetrandrine suppresses metastatic phenotype of prostate cancer cells by regulating Akt/mTOR/MMP-9 signaling pathway. Oncol Rep 35: 2880-2886, 2016.

13. Lin Y, Wang Y, Liu X, Yan J, Su L and Liu X: A novel derivative of tetrandrine $(\mathrm{H} 1)$ induces endoplasmic reticulum stress-mediated apoptosis and prosurvival autophagy in human non-small cell lung cancer cells. Tumour Biol 37: 10403-10413, 2016.

14. Wu K, Zhou M, Wu QX, Yuan SX, Wang DX, Jin JL, Huang J, Yang JQ, Sun WJ, Wan LH, et al: The role of IGFBP-5 in mediating the anti-proliferation effect of tetrandrine in human colon cancer cells. Int J Oncol 46: 1205-1213, 2015.

15. Zhang Y, Liu W, He W, Zhang Y, Deng X, Ma Y, Zeng J and Kou B: Tetrandrine reverses epithelial-mesenchymal transition in bladder cancer by downregulating Gli-1. Int J Oncol 48 : 2035-2042, 2016.

16. Wei N, Liu GT, Chen XG, Liu Q, Wang FP and Sun H: H1, a derivative of Tetrandrine, exerts anti-MDR activity by initiating intrinsic apoptosis pathway and inhibiting the activation of Erk1/2 and Akt1/2. Biochem Pharmacol 82: 1593-1603, 2011

17. Dang Y, Xu Y, Wu W, Li W, Sun Y, Yang J, Zhu Y and Zhang C: Tetrandrine suppresses lipopolysaccharide-induced microglial activation by inhibiting NF- $\mathrm{KB}$ and ERK signaling pathways in BV2 cells. PLoS One 9: e102522, 2014.

18. Meng LH, Zhang H, Hayward L, Takemura H, Shao RG and Pommier Y: Tetrandrine induces early G1 arrest in human colon carcinoma cells by down-regulating the activity and inducing the degradation of G1-S-specific cyclin-dependent kinases and by inducing p53 and p21Cip1. Cancer Res 64: 9086-9092, 2004.

19. He BC, Gao JL, Zhang BQ, Luo Q, Shi Q, Kim SH, Huang E, Gao Y, Yang K, Wagner ER, et al: Tetrandrine inhibits Wnt/及catenin signaling and suppresses tumor growth of human colorectal cancer. Mol Pharmacol 79: 211-219, 2011.

20. Bellomo C, Caja L and Moustakas A: Transforming growth factor $\beta$ as regulator of cancer stemness and metastasis. $\mathrm{Br} J$ Cancer 115: 761-769, 2016.

21. Lampropoulos P, Zizi-Sermpetzoglou A, Rizos S, Kostakis A, Nikiteas N and Papavassiliou AG: TGF-beta signalling in colon carcinogenesis. Cancer Lett 314: 1-7, 2012.

22. Zarzynska JM: Two faces of TGF-beta1 in breast cancer. Mediators Inflamm 2014: 141747, 2014.

23. Ouhtit A, Madani S, Gupta I, Shanmuganathan S, Abdraboh ME, Al-Riyami H, Al-Farsi YM and Raj MH: TGF- 32 : A novel target of CD44-promoted breast cancer invasion. J Cancer 4: 566-572, 2013.

24. Laverty HG, Wakefield LM, Occleston NL, O'Kane S and Ferguson MW: TGF-beta3 and cancer: A review. Cytokine Growth Factor Rev 20: 305-317, 2009.

25. Yu M, Trobridge P, Wang Y, Kanngurn S, Morris SM, Knoblaugh $S$ and Grady WM: Inactivation of TGF- $\beta$ signaling and loss of PTEN cooperate to induce colon cancer in vivo. Oncogene 33: 1538-1547, 2014.

26. Slattery ML, Herrick JS, Lundgreen A and Wolff RK: Genetic variation in the TGF- $\beta$ signaling pathway and colon and rectal cancer risk. Cancer Epidemiol Biomarkers Prev 20: 57-69, 2011

27. Kim YH, Kim G, Kwon CI, Kim JW, Park PW and Hahm KB TWIST1 and SNAI1 as markers of poor prognosis in human colorectal cancer are associated with the expression of ALDH and TGF- $\beta 1$. Oncol Rep 31: 1380-1388, 2014.

28. Principe DR, DeCant B, Staudacher J, Vitello D, Mangan RJ, Wayne EA, Mascariñas E, Diaz AM, Bauer J, McKinney RD, et al: Loss of TGF $\beta$ signaling promotes colon cancer progression and tumor-associated inflammation. Oncotarget: Jun 4, 2016 (Epub ahead of print)

29. Zunwen L, Shizhen Z, Dewu L, Yungui M and Pu N: Effect of tetrandrine on the TGF- $\beta$-induced smad signal transduction pathway in human hypertrophic scar fibroblasts in vitro. Burns 38: 404-413, 2012
30. Luo J, Deng ZL, Luo X, Tang N, Song WX, Chen J, Sharff KA, Luu HH, Haydon RC, Kinzler KW, et al: A protocol for rapid generation of recombinant adenoviruses using the AdEasy system. Nat Protoc 2: 1236-1247, 2007.

31. Chen XL, Ren KH, He HW and Shao RG: Involvement of PI3K/ AKT/GSK3beta pathway in tetrandrine-induced G1 arrest and apoptosis. Cancer Biol Ther 7: 1073-1078, 2008.

32. Goldwasser F, Bae I, Fornace AJ Jr and Pommier Y: Differential GADD45, p21CIP1/WAF1, MCL-1 and topoisomerase II gene induction and secondary DNA fragmentation after camptothecin-induced DNA damage in two mutant p53 human colon cancer cell lines. Oncol Res 8: 317-323, 1996.

33. Chen MC, Lee NH, Ho TJ, Hsu HH, Kuo CH, Kuo WW, Lin YM, Tsai FJ, Tsai $\mathrm{CH}$ and Huang CY: Resistance to irinotecan (CPT-11) activates epidermal growth factor receptor/nuclear factor kappa B and increases cellular metastasis and autophagy in LoVo colon cancer cells. Cancer Lett 349: 51-60, 2014.

34. Bhagya $\mathrm{N}$ and Chandrashekar KR: Tetrandrine - A molecule of wide bioactivity. Phytochemistry 125: 5-13, 2016.

35. Watabe T and Miyazono K: Roles of TGF-beta family signaling in stem cell renewal and differentiation. Cell Res 19: 103-115, 2009.

36. Neuzillet C, Tijeras-Raballand A, Cohen R, Cros J, Faivre S, Raymond $\mathrm{E}$ and de Gramont A: Targeting the TGF $\beta$ pathway for cancer therapy. Pharmacol Ther 147: 22-31, 2015.

37. Fabregat I, Fernando J, Mainez J and Sancho P: TGF-beta signaling in cancer treatment. Curr Pharm Des 20: 2934-2947, 2014.

38. Smith AL, Robin TP and Ford HL: Molecular pathways: Targeting the TGF- $\beta$ pathway for cancer therapy. Clin Cancer Res 18: 4514-4521, 2012.

39. Morrison CD, Parvani JG and Schiemann WP: The relevance of the TGF- $\beta$ Paradox to EMT-MET programs. Cancer Lett 341: 30-40, 2013.

40. Mancino M, Strizzi L, Wechselberger C, Watanabe K, Gonzales M, Hamada S, Normanno N, Salomon DS and Bianco C: Regulation of human Cripto-1 gene expression by TGF-beta1 and BMP-4 in embryonal and colon cancer cells. J Cell Physiol 215: 192-203, 2008.

41. Han S, Bui NT, Ho MT, Kim YM, Cho M and Shin DB: Dexamethasone inhibits TGF- $\beta 1$-induced cell migration by regulating the ERK and AKT pathways in human colon cancer cells via CYR61. Cancer Res Treat 48: 1141-1153, 2016.

42. Xu C, Liu W, Chen Z, Wang Y, Xiong Z and Ji Y: Effect of prenatal tetrandrine administration on transforming growth factor-betal level in the lung of nitrofen-induced congenital diaphragmatic hernia rat model. J Pediatr Surg 44: 1611-1620, 2009.

43. Guerrero F, Herencia C, Almadén Y, Martínez-Moreno JM, Montes de Oca A, Rodriguez-Ortiz ME, Diaz-Tocados JM, Canalejo A, Florio M, López I, et al: TGF- $\beta$ prevents phosphate-induced osteogenesis through inhibition of BMP and Wnt/ß-catenin pathways. PLoS One 9: e89179, 2014.

44. Vo BT, Morton D Jr, Komaragiri S, Millena AC, Leath C and Khan SA: TGF- $\beta$ effects on prostate cancer cell migration and invasion are mediated by PGE2 through activation of PI3K/AKT/ mTOR pathway. Endocrinology 154: 1768-1779, 2013.

45. Stipursky J, Francis D and Gomes FC: Activation of MAPK/ PI3K/SMAD pathways by TGF- $\beta(1)$ controls differentiation of radial glia into astrocytes in vitro. Dev Neurosci 34: 68-81, 2012.

46. Ciuffreda L, Falcone I, Incani UC, Del Curatolo A, Conciatori F, Matteoni S, Vari S, Vaccaro V, Cognetti F and Milella M: PTEN expression and function in adult cancer stem cells and prospects for therapeutic targeting. Adv Biol Regul 56: 66-80, 2014.

47. Dillon LM and Miller TW: Therapeutic targeting of cancers with loss of PTEN function. Curr Drug Targets 15: 65-79, 2014.

48. Molinari F and Frattini M: Functions and regulation of the PTEN gene in colorectal cancer. Front Oncol 3: 326, 2014. 